\title{
Reference evapotranspiration during rainy and dry seasons in Mossoró, RN, Brazil
}

\section{Evapotranspiração de referência nos períodos chuvoso e seco em Mossoró-RN}

\author{
Anna Kézia Soares de Oliveira ${ }^{1 *}$; Isaac Alves da Silva Freitas ${ }^{2}$; \\ Tecla Ticiane Félix da Silva ${ }^{3}$; José Espínola Sobrinho ${ }^{4}$; \\ Rudah Marques Maniçoba5; Wesley de Oliveira Santos ${ }^{4}$; \\ Joel Medeiros Bezerra ${ }^{4}$; Saulo Tasso Araujo da Silva ${ }^{4}$
}

\section{Highlights:}

The studied methods presented a better performance in the rainy year.

The Hargreaves-Original method presented a good estimate for both studied years.

The Hargreaves-Samani method showed no viability for use in the region.

\begin{abstract}
Mossoró, RN, Brazil, is considered one of the fruit growing centers of the Northeast region. This municipality has a persistent water deficit, with the need to develop irrigated agriculture with efficient water use and rational management of irrigation. The objective of this study was to evaluate estimation methods of reference evapotranspiration (ETo) for different climate conditions of Mossoró, comparing them with the standard Penman-Monteith-FAO 56 method. A daily data series of two distinct years, a rainy (2011) and a dry year (2012), was used. The data were obtained from the weather station of the Federal Rural University of the Semi-Arid Region (UFERSA). An analysis was performed to identify methods that best fit those of Penman-Monteith-FAO 56, and for this, ten methods were evaluated using statistical indices. The Penman-Original, Radiation-Temperature, and Hargreaves-Original methods stood out and satisfactorily met ETo estimation for the rainy season, while the Jensen-Haise, RadiationTemperature, and Hargreaves-Original methods achieved satisfactory performance for the dry season. The Hargreaves-Samani method did not demonstrate viability in the use of ETo estimation, as it was the worst method in both studied periods and is not recommended for irrigation management.
\end{abstract}

Key words: Agrometeorology. Irrigation management. Empirical methods.

1 Discente, Programa de Pós-Graduação em Fitotecnia, Universidade Federal Rural do Semi-Árido, UFERSA, Mossoró, RN, Brasil. E-mail: annakezia@outlook.com

2 M.e em Manejo de solo e Água, UFERSA, Mossoró, RN, Brasil. E-mail: isaacntn@outlook.com

3 Discente, Programa de Pós-Graduação em Engenharia Agrícola, Universidade Federal Rural de Pernambuco, UFRPE, Recife, PE, Brasil. E-mail: teclaticiane12@hotmail.com

4 Profs. Drs., UFERSA, Mossoró, RN, Brasil. E-mail: jespinola@ufersa.edu.br; wesley.santos@ufersa.edu.br; joel.medeiros@ ufersa.edu.br; saulo@ufersa.edu.br

5 Discente, Programa de Pós-Graduação em Manejo de Solo e Água, UFERSA, Mossoró, RN, Brasil. E-mail: rudahmanicoba@ gmail.com

* Author for correspondence 


\section{Resumo}

O município de Mossoró-RN é considerado uns dos polos fruticultores da região Nordeste. O município apresenta constante déficit hídrico, sendo necessário o desenvolvimento da agricultura irrigada com o uso eficiente da água, sendo fundamental o manejo racional da irrigação. Este trabalho objetivou avaliar para as condições climáticas de Mossoró-RN, diferentes métodos de estimativa da evapotranspiração de referência (ETo), comparando-os com o método padrão de Penman-Monteith-FAO 56. Foi utilizada uma série de dados diários de dois anos distintos, um ano chuvoso (2011) e outro seco (2012). Os dados foram obtidos na estação meteorológica da Universidade Federal Rural do Semi-Árido (UFERSA). Foi realizada análise visando identificar os métodos que melhor se ajustam ao de Penman-Monteith-FAO 56, e para isto, foram avaliados 10 métodos mediante índices estatísticos. Destacaram-se os métodos de Penman-Original, Radiação-Temperatura e Hargreaves-Original, os quais atenderam satisfatoriamente a estimativa da ETo para o período chuvoso, enquanto que os métodos de Jensen-Haise, RadiaçãoTemperatura e Hargreaves-Original obtiveram desempenho satisfatório para o período seco. O método de Hargreaves-Samani não demonstrou viabilidade na utilização de estimativa da ETo, pois foi o pior método em ambos os períodos estudados, não sendo recomendado para o manejo da irrigação.

Palavras-chave: Agrometeorologia. Manejo da irrigação. Métodos empíricos.

\section{Introduction}

The state of Rio Grande do Norte has favorable edaphoclimatic conditions for the cultivation of fruit plants, and irrigation allows producing a great variety of fruits with high economic return. However, drought events have inhibited the expression of this potential, which makes irrigation an indispensable activity, but this resource should be saved due to the current water scarcity.

Estimation of water consumption by crops stands out as one of the important variables to elaborate an irrigation project when the rational water use and maximization of production are desired.

Irrigation management requires, in addition to appropriate methods and technology, specific studies of water consumption for each crop at different times, places, and stages of development. An alternative for the efficient management of irrigation systems is to estimate reference evapotranspiration (ETo) (Silva, Carvalho, Silva, Camargo, \& Teodoro, 2011).

ETo is measured using relatively complex physical principles and techniques (Allen, Pereira, Howell, \& Jensen, 2011), and the most accurate direct form for its estimation is soil water balance using lysimeters. However, due to limitations associated with the method, the use of physicalmathematical models has become a practical alternative for ETo estimation (Carvalho, Rocha, Bonomo, \& Souza, 2015).

Among the various methods developed for estimating ETo using weather data, some of them may be inaccurate when the equation is not suitable for local conditions. Therefore, in an attempt to choose the best ETo estimation method for a given location, several studies comparing ETo estimation methods with the FAO-parameterized PenmanMonteith method have been performed for different regions as a way to verify the efficiency of methods, seeking the ETo estimation method that best represents the local conditions.

The correct ETo estimation is used as a basis for quantifying the actual water depth to be supplied to the soil during irrigation. Thus, estimating ETo accurately contributes to the rational use of natural water resources and reduces production costs (Empresa Brasileira de Pesquisa Agropecuária [EMBRAPA], 2010).

This study aimed to evaluate different ETo estimation methods for the climate conditions of Mossoró, RN, Brazil, and compare them with the standard Penman-Monteith-FAO 56 method. 


\section{Material and Methods}

This study was developed from meteorological data obtained through the weather station Jerônimo Rosado belonging to the Federal Rural University of the Semi-Arid Region (UFERSA), whose geographical coordinates are $5^{\circ} 12^{\prime} 49^{\prime \prime} \mathrm{S}$ and $37^{\circ} 19^{\prime} 43^{\prime \prime} \mathrm{W}$, with an altitude of $18 \mathrm{~m}$, in Mossoró in the state of Rio Grande do Norte.

According to the Köppen climate classification, the climate in the region is BSwh', i.e., warm and dry, with a rainy season in the summer until the autumn (Carmo, Espínola, \& Amorim, 1987).

The daily data used were mean, maximum, and minimum temperature $\left({ }^{\circ} \mathrm{C}\right)$ and relative humidity $(\%)$, wind speed $\left(\mathrm{m} \mathrm{s}^{-1}\right)$, and global radiation (MJ $\mathrm{m}^{-2}$ day $^{-1}$ ) for the period from January 1, 2011, to December 31, 2012. The year 2011 was considered rainy, with annual precipitation of $974.42 \mathrm{~mm}$, while 2012 was considered dry, with annual precipitation of $199.41 \mathrm{~mm}$. La Niña and El Niño occurred in 2011 and 2012, respectively. ETo calculations for all studied methods were performed using a spreadsheet.

Statistical analysis was performed to identify the methods that best fit that of Penman-Monteith-FAO 56 , searching for the method that best represented local conditions with a simpler methodology for estimating ETo. Ten methods were selected for this study: Penman-Original (Penman, 1948), Makkink (Makkink, 1957), Turc (Turc, 1961), Jensen-Haise (Jensen \& Haise, 1963), Garcia-Lopez (Garcia \& Lopez, 1970), Priestley-Taylor (Priestley \& Taylor, 1972), Hargreaves-Original (Hargreaves, 1974), Linacre (Linacre, 1977), HargreavesSamani (Hargreaves \& Samani, 1985), RadiationTemperature Oudin, Michel and Anctil (2005).

The evaluation of results of ETo estimation was performed for the daily period using regression analysis according to the linear model $y=a x+b$. The methodology adopted for the comparison of results was proposed by Allen, Jensen, Wright and
Burman (1989) and is based on the standard error of the estimate (SEE), calculated by Eq. 1 .

$$
\mathrm{SEE}=\left[\frac{\sum_{\mathrm{i}=1}^{\mathrm{n}}\left(\mathrm{Y}_{\mathrm{i}}-\mathrm{X}_{\mathrm{i}}\right)^{2}}{\mathrm{n}}\right]^{1 / 2}
$$

where SEE is the standard error of the estimate $\left(\mathrm{mm} \mathrm{d}^{-1}\right), \mathrm{Y}_{\mathrm{i}}$ is the reference evapotranspiration estimated by the standard method $\left(\mathrm{mm} \mathrm{d}^{-1}\right), \mathrm{X}_{\mathrm{i}}$ is the reference evapotranspiration obtained by the tested method $\left(\mathrm{mm} \mathrm{d}^{-1}\right)$, and $\mathrm{n}$ is the number of observations.

The approximation of ETo values, estimated by the studied methods in relation to the values obtained from the standard method, was obtained by an index of agreement (d) (Willmott, Ackleson \& Davis, 1985), whose values vary from zero (no agreement) to 1 (perfect agreement). The concordance index was obtained by Eq. 2. The model was validated by Pearson's correlation coefficient (r) (Eq. 3) and coefficient of confidence or performance (c) (Eq. 4).

$$
\begin{aligned}
& \mathrm{d}=1-\frac{\sum_{\mathrm{i}=1}^{\mathrm{n}}\left(\mathrm{Y}_{\mathrm{i}}-\mathrm{X}_{\mathrm{i}}\right)^{2}}{\sum_{\mathrm{i}=1}^{\mathrm{n}}\left[\left(\left|\mathrm{Y}_{\mathrm{i}}-\overline{\mathrm{x}}\right|\right)+\left(\left|\mathrm{X}_{\mathrm{i}}-\overline{\mathrm{x}}\right|\right)\right]^{2}} \\
& \mathrm{r}=\frac{\sum_{\mathrm{i}=1}^{\mathrm{n}}\left(\left|\mathrm{X}_{\mathrm{i}}-\overline{\mathrm{X}}\right|\right)\left(\mid \mathrm{Y}_{\mathrm{i}-\bar{Y} \mid)}\right.}{\sqrt{\sum_{\mathrm{i}=1}^{\mathrm{n}}\left(\mathrm{X}_{\mathrm{i}-}-\bar{X}\right)^{2}} \sqrt{\sum_{\mathrm{i}=1}^{\mathrm{n}}\left(\mathrm{Y}_{\mathrm{i}}-\bar{Y}\right)^{2}}} \\
& \mathrm{c}=\mathrm{r} \cdot \mathrm{d}
\end{aligned}
$$

where $\mathrm{d}$ is Willmott's index of agreement or adjustment, $\mathrm{Y}_{\mathrm{i}}$ is the reference evapotranspiration estimated by the standard method $\left(\mathrm{mm} \mathrm{d}^{-1}\right), \mathrm{X}_{\mathrm{i}}$ is the reference evapotranspiration obtained by the tested method $\left(\mathrm{mm} \mathrm{d}^{-1}\right), \mathrm{X}$ is the mean of reference evapotranspiration values obtained by the tested method $\left(\mathrm{mm} \mathrm{d}^{-1}\right), \mathrm{n}$ is the number of observations, $r$ is the Pearson's correlation coefficient, $Y$ is the mean of reference evapotranspiration values obtained by the standard method $\left(\mathrm{mm} \mathrm{d}^{-1}\right)$, and $\mathrm{c}$ is the coefficient of confidence or performance.

The variables were analyzed using descriptive statistics. The following hypothesis was verified for each simple linear regression of reference evapotranspiration: Ho: there is no simple linear 
regression $(\beta=0)$ and $H_{1}$ : there is simple linear regression $(\beta \neq 0)$ between the variables studied using the Student's t-test, according to the equation at significance level of 1 and 5\% probability.

$$
\mathrm{t}_{(\text {test })}=\frac{\widehat{\mathrm{b}}-\beta}{\mathrm{s}_{(\widehat{\mathrm{b}})}}
$$

where $\widehat{b}$ (regression or angular coefficient) is the estimator of the parameter $\beta$ of the linear regression equation and $s_{(\hat{b})}$ is the standard deviation of $\hat{b}$.

The coefficient of confidence or performance (c) is classified according to Camargo and Sentelhas (1997) as excellent $(\mathrm{c}>0.85)$, very good $(0.76<\mathrm{c}$ $<0.85)$, good $(0.66<\mathrm{c}<0.75)$, median $(0.61<\mathrm{c}<$ $0.65)$, poor $(0.51<\mathrm{c}<0.60)$, bad $(0.41<\mathrm{c}<0.50)$, and very bad $(\mathrm{c}<0.40)$.

\section{Results and Discussion}

\section{Rainy season}

Figures $1 \mathrm{~A}$ and 1B illustrate the monthly distribution of ETo by different estimation methods, as well as compared with the standard model Penman-Monteith-FAO 56 for the rainy season. ETo showed throughout the year different ranges of variation. The tested methods showed a high similarity of temporal distribution with the Penman-Monteith-FAO 56 method. For all models, ETo estimations were lower in the period of highest precipitation and coldest of the year (first semester), while the highest values were recorded from August to December, which refers to the period of higher temperatures and lower humidity in the region under study.

Table 1 shows the values of the statistical indices between methods compared to the standard method, referring to the rainy year and for Mossoró, RN. The results show that the Radiation-Temperature, Hargreaves-Original, and Penman-Original methods had the lowest SEE, with values of $0.543,0.591$, and $0.659 \mathrm{~mm} \mathrm{day}^{-1}$, respectively. On the other hand, Makkink, Garcia-Lopez and Jensen-Haise methods showed the highest SEE, with values of 1.403 , 1.295 , and $1.176 \mathrm{~mm} \mathrm{day}^{-1}$, respectively. Pearson's correlation coefficient (r) indicates the degree of correlation between the ETo estimation models tested in relation to the Penman-Monteith-FAO 56 method under local climate conditions. According to the correlation coefficient, all methods showed values around 0.815 to 0.933 , indicating they present a very strong correlation when compared to the FAO method.

Among the evaluated models, the RadiationTemperature, Penman-Original, and HargreavesOriginal methods presented the best adjustments, being classified as very good by the coefficient of performance or confidence $c$, with values of 0.840 , 0.830 , and 0.804 , respectively. It evidenced that these methods can be used in the proposed form to estimate the ETo under the conditions of Mossoró, RN, while the Hargreaves-Samani method presented the worst performance, with index $c=0.301$, being classified as very bad.

Lucena, Silva, Ribeiro, Simeão and Lucena (2016) evaluated ETo estimations for the municipality of Bom Jesus, PI, and found that the Hargreaves-Samani method had a poor performance in the rainy season $(c=0.575)$. The HargreavesSamani method is recommended for the semi-arid condition and hence its performance presents a reduction in the accuracy of evapotranspiration estimation during rainy months (Alencar, Delgado, Almeida, \& Wanderley, 2011). 

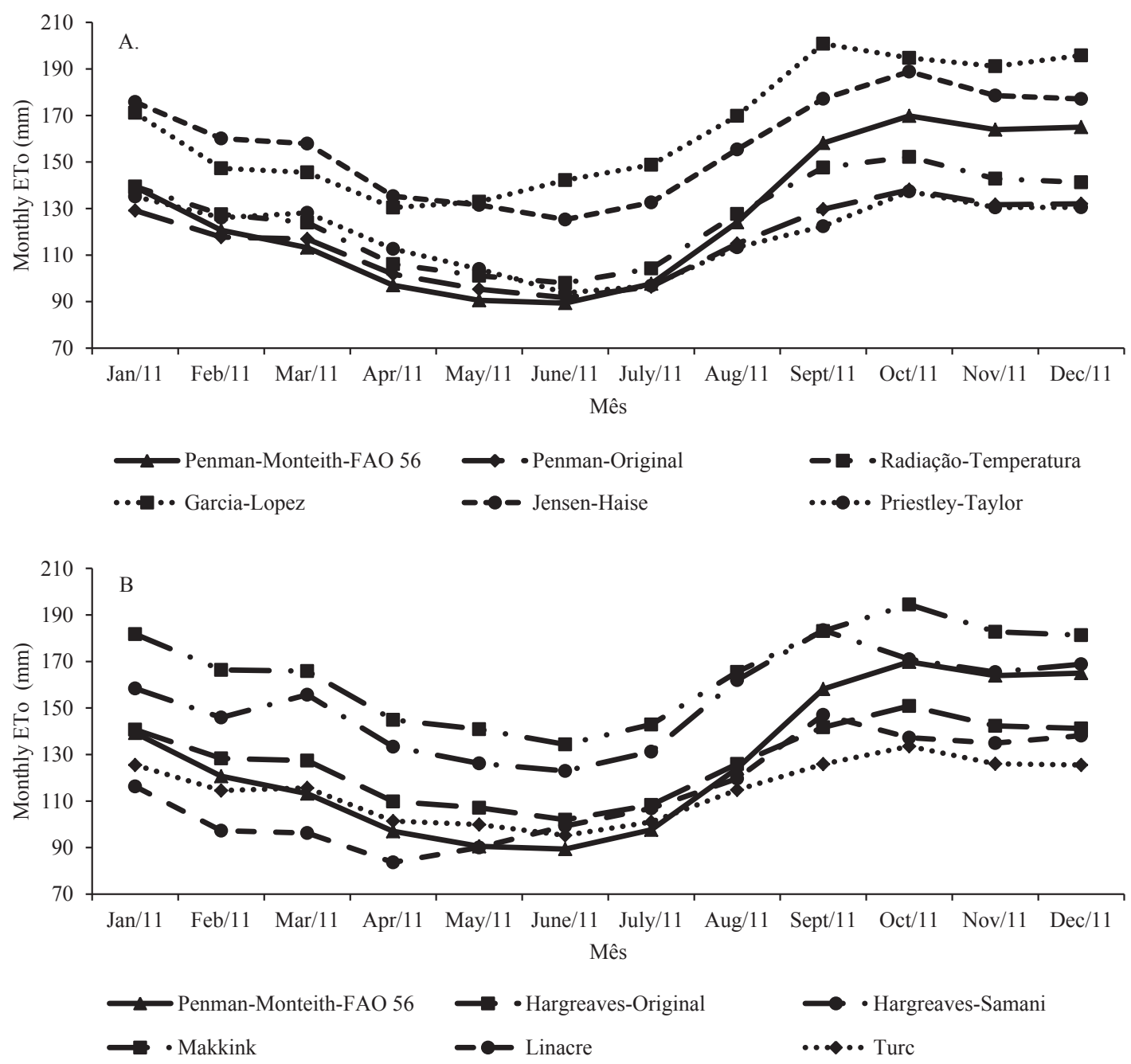

Figure 1. Monthly distribution of ETo estimated through indirect methods during a rainy year in Mossoró, RN, Brazil.

Table 1

Statistical indicators of the comparison between different methods of ETo estimation with the standard method Penman-Monteith-FAO 56 on a daily scale for the rainy season in Mossoró, RN, Brazil

\begin{tabular}{|c|c|c|c|c|c|c|}
\hline Method & SEE $\left(m m\right.$ dia $\left.^{-1}\right)$ & $\mathbf{R}^{2}$ & $\mathbf{r}$ & d & $\mathrm{C}$ & Performance \\
\hline Penman-Original & 0.659 & 0.871 & 0.933 & 0.890 & 0.830 & Very good \\
\hline Makkink & 1.403 & 0.746 & 0.864 & 0.741 & 0.641 & Median \\
\hline Turc & 0.778 & 0.740 & 0.860 & 0.756 & 0.650 & Median \\
\hline Jensen-Haise & 1.176 & 0.778 & 0.882 & 0.808 & 0.713 & Good \\
\hline Garcia-Lopez & 1.295 & 0.863 & 0.929 & 0.743 & 0.691 & Good \\
\hline Priestley-Taylor & 0.772 & 0.663 & 0.815 & 0.839 & 0.683 & Good \\
\hline Hargreaves-Original & 0.591 & 0.761 & 0.872 & 0.922 & 0.804 & Very good \\
\hline Linacre & 0.786 & 0.750 & 0.866 & 0.773 & 0.670 & Good \\
\hline Hargreaves-Samani & 1.052 & 0.702 & 0.838 & 0.359 & 0.301 & Very bad \\
\hline Radiation-Temperature & 0.543 & 0.797 & 0.893 & 0.941 & 0.840 & Very good \\
\hline
\end{tabular}

Standard error of the estimate (SEE), coefficient of determination $\left(\mathrm{R}^{2}\right)$, Pearson's correlation (r), Willmott agreement (d), and coefficient of confidence and performance (c). 
Figure 2 shows linear regressions between daily reference evapotranspiration values estimated by the methods analyzed in this study as a function of the standard method Penman-Monteith-FAO 56 for the rainy season. The Penman-Original method presented the highest coefficient of determination $\left(r^{2}=0.871\right)$. The lowest coefficient was presented by the Priestley-Taylor method $\left(r^{2}=0.663\right)$. The
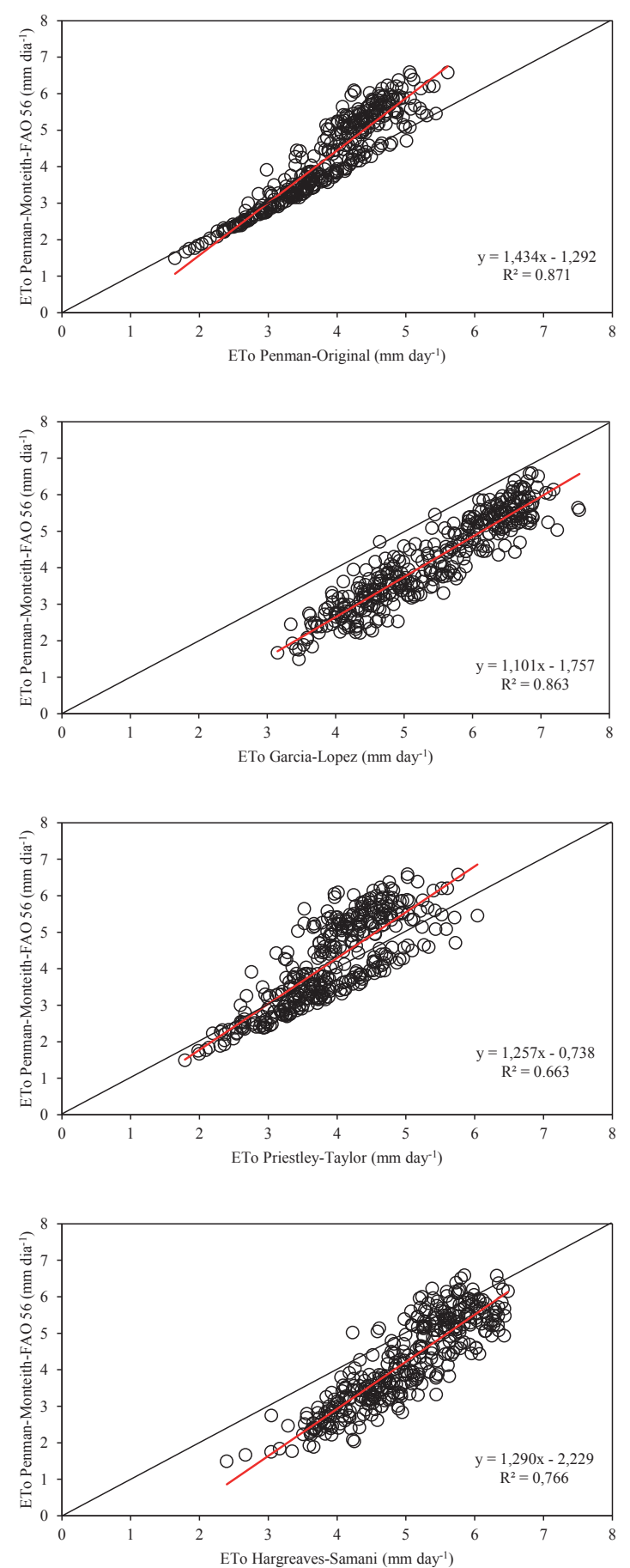

Penman-Original method presented values closest to those estimated by the Penman-Monteith-FAO 56 method, with a good adjustment to the standard method in ETo determination for Mossoró, RN, during the rainy season, which could have been presumed since Penman-Monteith-FAO 56 is a method adjusted from the Penman-Original method.
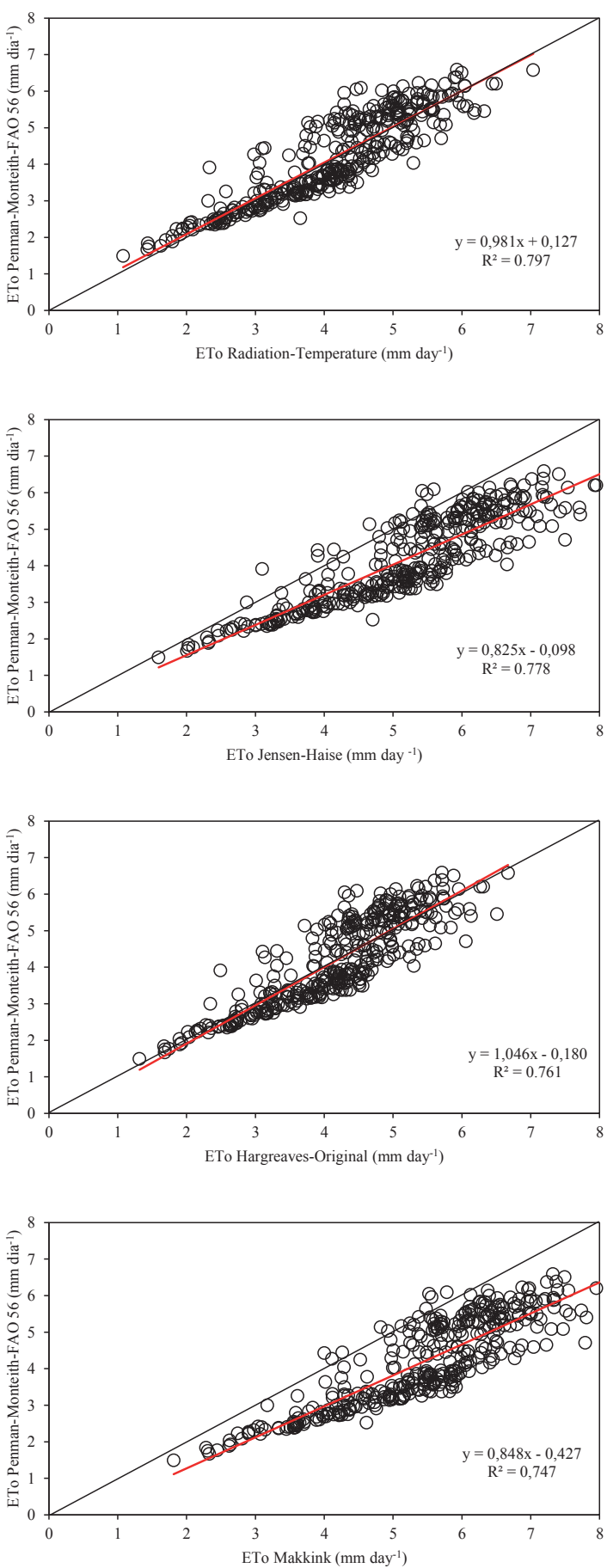

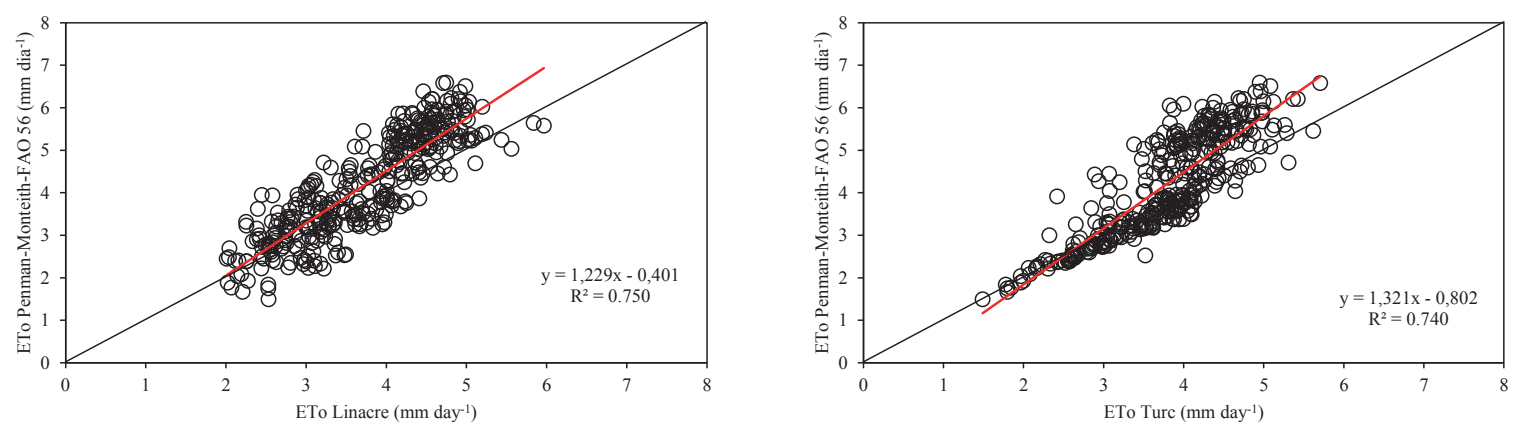

Figure 2. Linear regression between the daily values of reference evapotranspiration (ETo) estimated by different methods and compared to the standard method Penman-Monteith-FAO 56 during the rainy year of 2011 in Mossoró, RN, Brazil.

\section{Dry season}

The monthly distribution of ETo models compared to the standard model Penman-MonteithFAO 56 for the dry season is shown in Figures $3 \mathrm{~A}$ and $3 \mathrm{~B}$. During the dry year, ETo also showed similarity in the trend of curves for all models. ETo estimations were more constant when compared to the rainy year due to the small annual variability of climate input parameters. A slight decrease was also observed in values only in the coldest period of the year, i.e., from May to July.
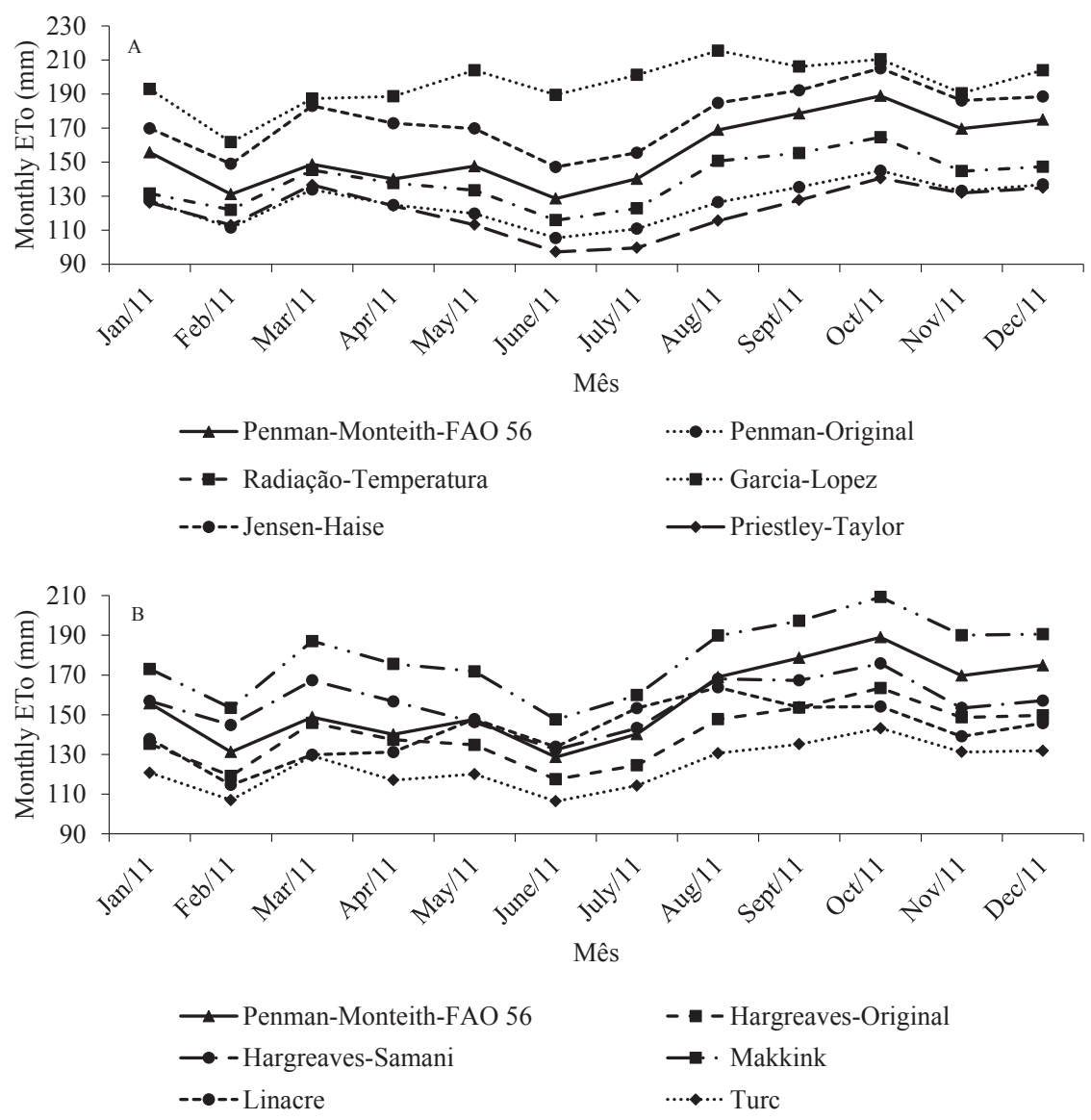

Figure 3. Monthly distribution of ETo estimated through indirect methods during a dry year in Mossoró, RN, Brazil. 
The results of the statistical indicators of performance analysis of the ETo estimation methods for the dry season in Mossoró, RN, are shown in Table 2. The Hargreaves-Samani, RadiationTemperature, and Hargreaves-Original methods presented the lowest SEE, with values of 0.665 , 0.782 , and $0.792 \mathrm{~mm} \mathrm{day}^{-1}$, respectively. On the other hand, Garcia-Lopez, Priestley-Taylor and Turc methods presented the highest SEE, with values of $1.456,1.304$, and $1.211 \mathrm{~mm} \mathrm{day}^{-1}$, respectively.

Table 2

Statistical indicators of the comparison between different estimation methods of ETo with the standard method Penman-Monteith-FAO 56 on a daily scale for the dry season in Mossoró, RN, Brazil

\begin{tabular}{|c|c|c|c|c|c|c|}
\hline Method & SEE $\left(\mathrm{mm} \mathrm{dia} \mathrm{di}^{-1}\right)$ & $\mathbf{R}^{2}$ & $\mathbf{r}$ & d & c & Performance \\
\hline Penman-Original & 1.075 & 0.768 & 0.876 & 0.611 & 0.535 & Poor \\
\hline Makkink & 1.059 & 0.721 & 0.849 & 0.758 & 0.644 & Median \\
\hline Turc & 1.211 & 0.723 & 0.850 & 0.577 & 0.491 & $\mathrm{Bad}$ \\
\hline Jensen-Haise & 0.938 & 0.743 & 0.862 & 0.796 & 0.686 & Good \\
\hline Garcia-Lopez & 1.456 & 0.582 & 0.763 & 0.538 & 0.410 & Bad \\
\hline Priestley-Taylor & 1.304 & 0.538 & 0.734 & 0.534 & 0.392 & Very bad \\
\hline Hargreaves-Original & 0.792 & 0.732 & 0.855 & 0.792 & 0.678 & Good \\
\hline Linacre & 0.818 & 0.458 & 0.676 & 0.705 & 0.477 & $\mathrm{Bad}$ \\
\hline Hargreaves-Samani & 0.665 & 0.536 & 0.732 & 0.775 & 0.567 & Poor \\
\hline Radiation-Temperature & 0.782 & 0.852 & 0.852 & 0.810 & 0.690 & Good \\
\hline
\end{tabular}

Standard error of the estimate (SEE), coefficient of determination $\left(\mathrm{R}^{2}\right)$, Pearson's correlation (r), Willmott agreement (d), and coefficient of confidence and performance (c).

According to Pearson's correlation coefficient (r), the studied methods presented values around 0.676 to 0.876 , indicating that the methods presented a positive moderate to very strong correlation with the FAO method.

Among the evaluated methods, RadiationTemperature, Jensen-Haise, and HargreavesOriginal showed the best adjustments, being classified as good by the coefficient of confidence (c), with values of $0.690,0.686$, and 0.678, respectively. Moreover, these models had high values of coefficients of determination $\left(\mathrm{r}^{2}\right)$ above 0.7 and Pearson's correlation (r) above 0.80 , indicating a very strong positive correlation with the standard method. However, the Priestley-Taylor method was classified as very bad. It is important to highlight that no model had a very good performance index in this dry year.

Figure 4 shows the linear regressions between daily ETo values estimated by the methods as a function of the Penman-Monteith-FAO 56 method for the dry season. The best results of $\mathrm{r}^{2}$ were found for the Penman-Original method, with a value of 0.768 , although its performance was poor for the dry year. The Jensen-Haise method also showed a strong correlation with the Penman-MonteithFAO 56 method, with an $\mathrm{r}^{2}$ equal to 0.743 . Its good performance in both years allows it to stand out among the other tested models. Gonçalves, Feitosa, Carvalho, Gomes and Valnir (2009) conducted studies in Sobral, CE, and also found a performance classified as good for the Jensen-Haise method, with confidence and performance indices (c) of 0.69 , correlation coefficient (r) of 0.76 , and standard error of the estimate (SEE) of $0.97 \mathrm{~mm} \mathrm{day}^{-1}$.

In the region of Serra da Mantiqueira, MG, Pereira, Yanage, Mello, Silva and Silva (2009) found the same very bad performance for the PriestleyTaylor method, which showed a significant reduction in the statistical indicators in the dry season when 
compared to those obtained for the rainy season. According to the authors, the variability in the performance of the Priestley-Taylor equation for
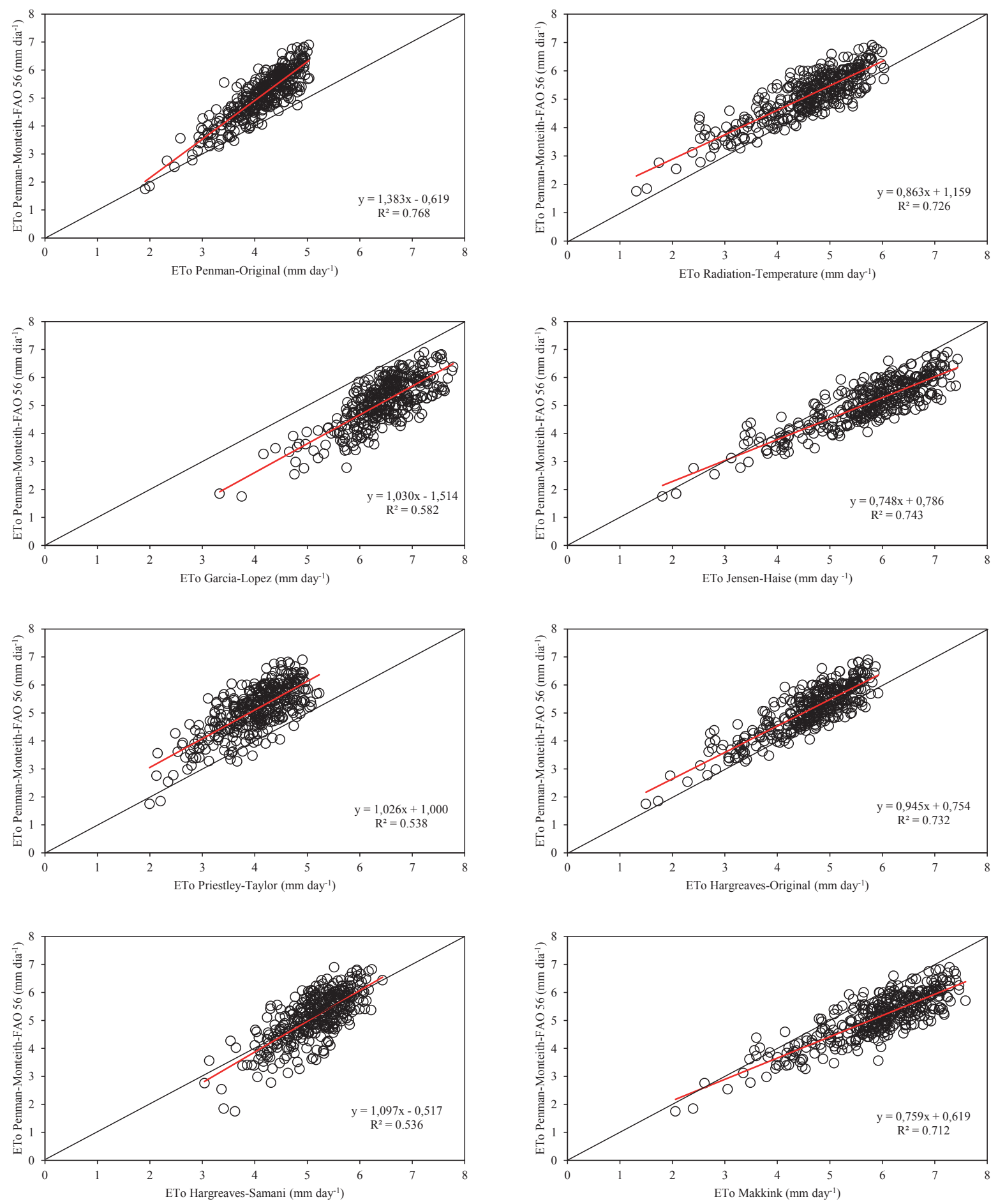

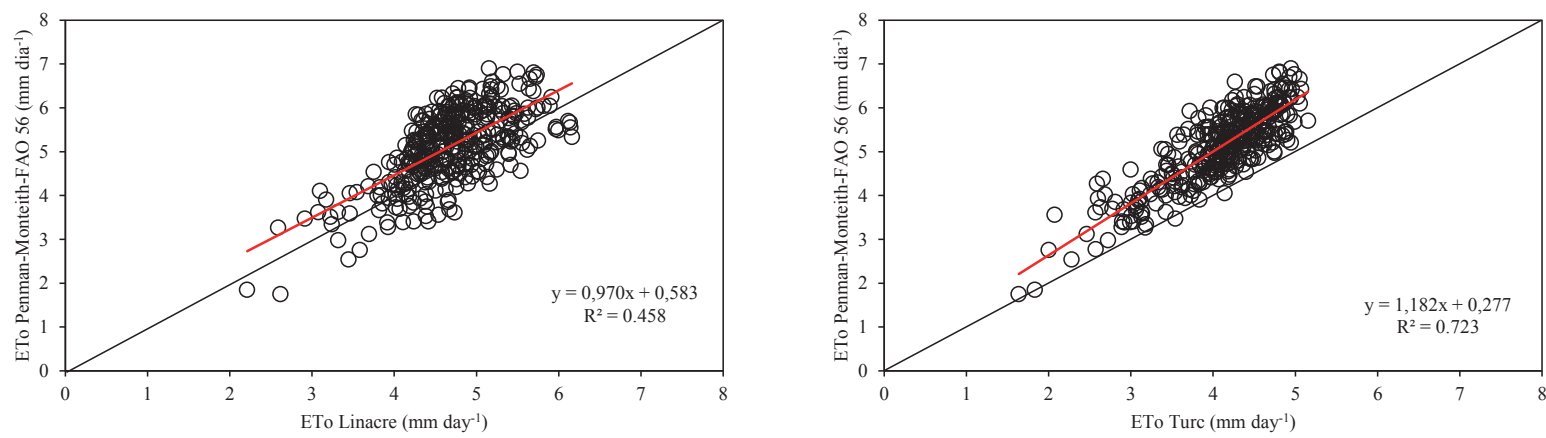

Figure 4. Linear regression between the daily values of reference evapotranspiration (ETo) estimated by different methods and compared to the standard method Penman-Monteith-FAO 56 during the dry year of 2012 in Mossoró, RN, Brazil.

In both periods, the Hargreaves-Samani method had the worst performance, not being recommended to calculate ETo estimation for the studied site. The Garcia-Lopez and Linacre methods presented performance considered as good for the rainy season and bad for the dry season. The Makkink method presented a median performance for both periods.

\section{Conclusions}

Among the methods evaluated for the region of Mossoró, RN, the best performances were obtained in the rainy year, ranging from median to very good, with the Penman-Original, Radiation-Temperature, and Hargreaves-Original methods standing out. The exception was observed for the Hargreaves-Samani method, with a very bad performance.

For the dry year, the performance of methods worsened from poor to good, especially the JensenHaise, Radiation-Temperature, and HargreavesOriginal methods, which presented a good performance.

The Hargreaves-Samani method presented no viability when using its equation to estimate reference evapotranspiration in both years (rainy and dry) in Mossoró, RN, as it stood out as the worst method in both studied seasons, and is not recommended for irrigation management in the municipality.

\section{References}

Alencar, L. P., Delgado, R. C., Almeida, T. H., \& Wanderley, H. S. (2011). Comparação de diferentes métodos de estimativa diária da evapotranspiração de referência para a região de Uberaba. Revista Brasileira de Ciências Agrárias, 6(2), 337-343. doi: 10.5039/agraria.v6i2a1124

Allen, R. G., Pereira, L. S., Howell, T. A., \& Jensen, M. E. (2011). Evapotranspiration information reporting: I. Factors governing measurement accuracy. Agricultural Water Management, 98(6), 899-920. doi: 10.1016/j.agwat.2010.12.015

Allen, R. G.; Jensen, M. E.; Wright, J., \& Burman, R. D. (1989). Operational estimates of reference evapotranspiration. Agronomy Journal, 81(4), 650662. doi: 10.2134 /agronj1989.00021962008100040 019x

Camargo, A. P., \& Sentelhas, P. C. (1997). Avaliação do desempenho de diferentes métodos de estimativa da evapotranspiração potencial no estado de São Paulo. Revista Brasileira de Agrometeorologia, 5(1), 89-97.

Carmo, Fº, Espínola, J., Sob ${ }^{\circ}$., \& Amorim, A. P. (1987). Dados meteorológicos de Mossoró (janeiro de 1898 a dezembro de 1986). Mossoró: ESAM /Fundação Guimarães Duque. (Coleção Mossoroense, 341).

Carvalho, D. F., Rocha, H. S., Bonomo, R., \& Souza, A. D. (2015). Estimativa da evapotranspiração de referência a partir de dados meteorológicos limitados. Pesquisa Agropecuária Brasileira, Brasília, 50(1), 1-11. doi: 10.1590/S0100-204X2015000100001

Empresa Brasileira de Pesquisa Agropecuária. (2010). Evapotranspiração: uma revisão sobre os métodos empíricos. Goiás: EMBRAPA Arroz e Feijão. 
Garcia, B. J., \& Lopez, D. (1970). Formula para el caçulo de la evapotranspiracion potencial adaptada al tropico $\left(15^{\circ} \mathrm{N}-15^{\circ} \mathrm{S}\right)$. Agronomia Tropical, 20(5), 335-345.

Gonçalves, F. M., Feitosa, H. O., Carvalho, C. M., Gomes, R. R., Fo , \& Valnir, M. V. Jr. (2009). Comparação de métodos da estimativa de evapotranspiração de referência para o município de Sobral, Ceará. Revista Brasileira de Agricultura Irrigada, 3(2), 7177, 2009. doi: 10.7127/rbai.v3n200016

Hargreaves, G. H., \& Samani, Z. A. (1985). Reference crop evapotranspiration from ambient air temperature. Applied Engineering in Agriculture, 1(2), 96-99. doi: 10.13031/2013.26773

Hargreaves, G. H. (1974). Estimation of potential and crop evapotranspiration. Transactions of the ASAE, 17(1), 701-704.

Jensen, M. E., \& Haise, H. R. (1963). Estimating evapotranspiration from solar radiation. Journal of the Irrigation and Drainage Division ASCE, 4(1), 15-41.

Linacre, E. T. A. (1977). Simple formula for estimating evapotranspiration rates in various climates, using temperature data alone. Agricultural Meteorology, $18(1), 409-424$.

Lucena, F. A. P., Silva, E. M., Ribeiro, A. A., Simeão, M., \& Lucena, J. P. A. P. (2016). comparação entre métodos de estimativa da evapotranspiração de referência no município de Bom Jesus, PI. Revista Brasileira de Agricultura Irrigada, 10(3), 663-675. doi: 10.7127/rbai.v10n300404

Makkink, G. F. (1957). Testing the Penman formula by means of lysimeters. Journal of the Institution of Water Engineers, 11(3), 277-288.
Oudin, L., Michel, C., \& Anctil, F. (2005). Which potential evapotranspiration input for a lumped rainfall-runoff model? Part 1- Can rainfall runoff models effectively handle detailed potential evapotranspiration inputs? Journal of Hydrology, 303(1-4), 290-306. doi: 10.1016/j.jhydrol.2004.08.025

Penman, H. L. (1948). Natural evaporation from open water, bare soil and grass. Proceedings of Royal Society-Series A, 193(1), 120-145. doi: 10.1098/ rspa. 1948.0037

Pereira, D. R., Yanage, S. N. M., Mello, C. R., Silva, A. M., \& Silva, L. A. (2009). Desempenho de métodos de estimativa da evapotranspiração de referência para a região da Serra da Mantiqueira, MG, Ciência Rural, 39(9), 2488-2493. doi: 10.1590/S010384782009000900016

Priestley, C. H. B., \& Taylor, R. J. (1972). On the assessment of surface heat flux and evaporation using large-scale parameters. Monthly Weather Review, $100(2)$, 81-92. doi: 10.1175/1520-0493(1972)100 $<0081$ :OTAOSH $>2.3 . \mathrm{CO} ; 2$

Silva, V. J., Carvalho, H. P., Silva, C. R., Camargo, R., \& Teodoro, R. E. F. (2011). Desempenho de diferentes métodos de estimativa da evapotranspiração de referência diária em Uberlândia, MG. Bioscience Journal, 27(1), 95-101.

Turc, L. (1961). Evaluation des besoins en eau d' irrigation, évapotranspiration potentielle, formule simplifée et mise à jour. Annals of Agronomy, 12(1), 13-49, 1961.

Willmott, C. J., Ackleson, S. G., \& Davis, R. E. (1985). Statistics for the evaluation and comparison of models. Journal of Geophysical Research, 90(C5), 8995-9005. doi: 10.1029/JC090iC05p08995 
